IP Periodica Polytechnica Civil Engineering

60(1), pp. 75, 82,2016

DOI: $10.3311 / P P c i .7625$

Creative Commons Attribution (1)

RESEARCH ARTICLE

\section{Comparative Evaluation of Behavior Factor of SMRF Structures for Near and Far Fault Ground Motions}

\author{
Vafa Soltangharaei, Morteza Razi, Mohsen Gerami
}

Received 16-07-2015, revised 20-06-2015, accepted 07-09-2015

\begin{abstract}
In common design codes, earthquake loads are reduced by a coefficient (behavior factor) which depends on nonlinear seismic performance of structure during earthquake event. Nonlinear performance of structures depends on structural properties and ground motion characteristics. There are different methods for estimation of seismic response parameters such as behavior factor. One of the approaches is using incremental dynamic analysis. This paper gives estimations of behavior factor for special moment-resisting steel frames under near and far fault records using incremental dynamic analyses. Three moment resisting frames with, 3, 6, and 10 stories, are considered for evaluations employing two performance levels (Life Safety and Collapse Prevention). One aspect of difference among earthquake records is existence of velocity pulse in their time-history. This issue is investigated through evaluation of $R$ factor for three frames. It is shown that behavior factor for near fault records is averagely $23 \%$ less than far fault records.
\end{abstract}

\section{Keywords}

Behavior factor - moment resisting frame $\cdot$ incremental dynamic analysis $\cdot$ near fault ground motion $\cdot$ performance limit state

\footnotetext{
Vafa Soltangharaei

Department of Civil Engineering, Semnan University, 3513119111, Semnan,

e-mail:v.soltan@students.semnan.ac.ir
} Iran

\section{Morteza Razi}

Department of Civil Engineering, Semnan University, 3513119111, Semnan, Iran

e-mail: m.razi@students.semnan.ac.ir

\section{Mohsen Gerami}

Department of Civil Engineering, Semnan University, 3513119111, Semnan, Iran

e-mail: mgerami@semnan.ac.ir

\section{Introduction}

Moment-resisting steel frames (MRFs) are frequently used as lateral load resisting system in building structures located in high seismic regions. High ductility, economic solution options, and some architectural circumstances are of the advantages of this system. To assure structural stability, non-degrading hysteretic behavior of beam-to-column connections, and restricting the P- $\Delta$ effect, it is required to limit the lateral deflections. In addition, the lateral drifts should be controlled to avoid possible damage in structural and non-structural components. Therefore, performance levels of MRF systems can be defined by maximum inter-story drift ratios. Such definition makes it possible to identify performance levels using displacement demand values obtained from nonlinear dynamic analysis. To quantify the response parameters of a structure, for different seismic intensities, incremental dynamic analysis (IDA) can be employed. By this method, required data for calculation of behavior factor $(R$ factor) can be obtained for different performance levels (Including Life Safety (LS) and Collapse Prevention (CP) limit states). In addition, pushover analysis can be used for determination of the earthquake intensities corresponding to formation of significant plasticity in structure. Employing the results of linear and nonlinear time-history analyses, behavior factor can be evaluated by a procedure described by Asgarian and Shokrgozar, [1].

Several researches have been conducted concerning the seismic performance of MRF structures. Asgharian et al. [2] studied the seismic performance of MRF structures using IDA analysis approach. They concluded that special moment resisting frames (SMRFs) possessed a high level of ductility, which provided high level of confidence, both for Immediate Occupancy (IO) and Collapse Prevention (CP) limit states. For low-rise buildings, SMRFs and intermediate moment resisting frames (IM$\mathrm{RFs}$ ) exhibited equal level of seismic performance, for IO and $\mathrm{CP}$ performance levels. Luco and Cornell [3] assessed seismic behavior of steel moment frames. They considered the effect of beam-to-column connection fracture on the seismic performance of MRF structures. Yun et al. [4], applied nonlinear dynamic analysis and reliability theory to develop a procedure for estimation of confidence level for different performance levels. 
Özhendekci et al. [5] evaluated the effect of span length of moment frames on the seismic performance and design economy.

Attention of the design codes to performance-based design is growing fast. Xue et al. [6] presented a methodology for performance-based design of structures. Therefore, deriving seismic parameters for different performance states becomes more significant to researchers. Seismic performance parameters of moment resisting frames with semi rigid connection were evaluated by Aksoylar et al. [7]. They calculated $R$ factor values using structural response data obtained from time history analyses.

If it is intended to design the structures using linear analysis method with consideration of the seismic performance levels, definition of performance based behavior factor is required.

In this method, behavior factor is assigned to a specific performance level, rather than ultimate limit state. Therefore, ultimate capacity of structure must be defined based on performance levels. This is an innovation aimed at the inclusion of performancebased design concept in conventional design methods based on linear analysis approaches. In other words, definition of behavior factor associated with predetermined performance levels is a simple method to indirectly ensure that the expected performance level is satisfied. In this procedure, the effects of near fault records are included to facilitate the design of structures located in vicinity of seismically active faults. In this paper, using the implications of FEMA 356 [8], earthquake intensity values corresponding to LS and CP limit states are determined. Then, $R$ factor values are evaluated for different limit states (performance levels, LS and CP). Two sets of ordinary and near-fault records are selected for evaluation, thereby investigating the variation of $R$ factor values for near and far fault ground motion records.

\section{Near-fault ground motions}

Near fault ground motions usually have at least one pulse or more in their velocity time-histories. Velocity pulses typically form in the direction, which makes right angle with respect to the fault rupture line. It is proved that near-fault ground motion records have larger elastic spectral accelerations in the moderate to long periods range, imposing severe damage and larger time history response to structures [9].

Kalkan et al. [10] showed that typical steel moment frames undergo large lateral displacements at the arrival of the velocity pulses that require the structure to dissipate considerable input energy through a single or relatively few cycles. Gerami and Abdollahzadeh [11] evaluated dynamic response of five momentresisting frames under near fault records. They concluded that forward directivity caused large impacts on the local and global demand parameters of the model structures. They showed that near fault records caused decrease in bending strength and ductility of the columns by $30 \%$ and $40 \%$, averagely.

There are limited numbers of researches to evaluate the $R$ factor considering records with pulse effects. Some researchers demonstrated that behavior factors for near-fault ground mo- tions with forward directivity are different from ones for ordinary ground motions. They concluded that response reduction factor was less for forward directivity near fault ground motions compared to ordinary records [12]. In this paper, influence of near fault ground motion on elastic design, is under consideration by observing variation of $R$ factor quantities. Therefore, behavior factor of special moment resisting frames is estimated for two sets of near and far fault records, and the average $R$ factors are compared. Other seismic performance parameters (such as over-strength and ductility) are also evaluated. Response quantities are obtained from linear and nonlinear incremental dynamic analyses. To select near fault records, the methodology proposed by Baker [13] is followed.

\section{Behavior factor}

Design codes usually allow the use of linear elastic procedures to design common structures. Some researchers developed algorithms to consider the inelastic seismic behavior of structures in linear elastic design procedures. The most applicable method to this end, is definition of a coefficient to reduce design base shear, taking advantage of nonlinear seismic capacity of the structure. This procedure, equivalent linear static method, is based on the use of $R$ factor. The capacity of structure to dissipate seismic energy depends on its ability to deflect nonlinearly. $R$ factor depends on some parameters such as overstrength and ductility. Over-strength comes back to the fact that the maximum lateral strength of a structure generally exceeds its design strength. Also, structural ductility $(\mu)$ can be estimated by dividing maximum allowable nonlinear displacement by displacement value corresponding to the yield point (Fig. 1. As the ductility goes up, "behavior factor due to ductility" increases. Higher ductility results in larger capacity to dissipate input seismic energy.

The $R$ factor proposed in ATC-34 [14] is calculated as the product of three factors: over-strength, ductility, and redundancy factor. Behavior factor of special moment-resisting structures is proposed 8, according to American Society of Civil Engineers (ASCE 7-10) [15].

There are different analytical approaches to calculate behavior factor of structures. Izadinia et al. [16] derived seismic behavior parameters of three steel moment resisting frames involving 3, 9, and 20 stories (adopted from SAC steel project), using conventional and adaptive pushover methods. In addition, Kang and Choi [17] developed a new procedure to calculate behavior factor of steel moment frames by multiplying some parameters (including ductility factor of SDOF, MDOF modification factor and over strength factor). Some other researchers utilized nonlinear dynamic procedure to estimate $R$ factor values. For instance, Karavasilis et al. [18] utilized nonlinear time-history analysis to estimate performance-based $R$ factor for plane steel moment frames, for different limit states. Also, they evaluated the effect of story height and number of bays on the behavior coefficient of steel moment frame structures. Seismic parameters 
of a kind of bracing system configuration ("gate braced frame"), using incremental dynamic analysis, are derived by Fanaie and Ezzatshoar [19]. Asgarian et al. [1] utilized static linear and nonlinear time-history analyses to assess the behavior factor of buckling-restrained braced frames (BRBFs). In this paper, the response parameters are estimated from linear and nonlinear incremental dynamic and pushover analyses.

Nonlinear behavior curve of structures can be idealized and converted to bilinear elastic-plastic relation (Fig. 1). In this method, the yield force of structure is denoted as $V_{y}$ and the yield displacement as $\Delta_{y}$. Also, $V_{e}$ corresponds to the elastic response base shear which can be obtained from elastic dynamic analyses of structures.

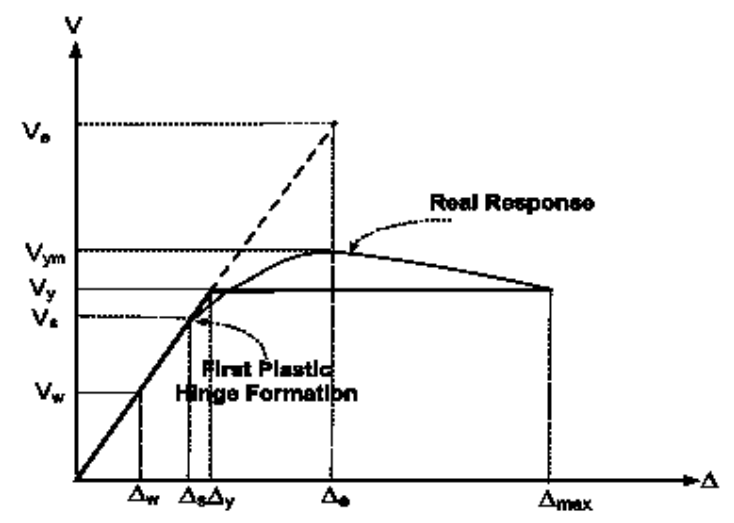

Fig. 1. Structural response parameters.

$V_{y}$ denotes maximum base shear of elastic-perfectly-plastic behavior. The ratio of maximum base shear (considering elastic behavior), $V_{e}$, to maximum base shear in elastic-plastic behavior, $V_{y}$, is called "force reduction due to ductility", $R_{\mu}$, (Eq. (1)).

$$
R_{\mu}=\frac{V_{e}}{V_{y}}
$$

The over-strength factor is defined as the ratio of the maximum base shear in elastic-plastic behavior $\left(V_{y}\right)$ to the base shear corresponding to start of yielding in structural elements, $V_{s}$, (Eq. (2)).

$$
R_{s 0}=\frac{V_{y}}{V_{s}}
$$

ASCE 07-10 suggests three for over-strength factor of SMRF structures. In this paper, over-strength factor is calculated from Eq. (2). Over-strength factor value is also dependent o nominal properties of the material. Denoting this over-strength factor as $R_{s o}$, the actual over-strength factor $R_{s}$ (which can be used to compute $R$ factor), should consider the contribution of some other factors, (Eq. (3)), [1].

$$
R_{s}=R_{s 0} \times F_{1} \times F_{2} \times \ldots \times F_{n}
$$

Where $F_{1}$ is used to account for difference between actual static yield strength and nominal static yield strength. For structural steel, statistical study shows that the value of $F_{1}$ may be taken as $1.05[20] . F_{2}$ may be used to consider the increase in yield stress due to strain rate effect during an earthquake excitation. Value of $1.1,10 \%$ increase for the strain rate effect, can be considered for $F_{2}$ parameter [1]. As St-37 steel is used for all structural components, $F_{1}$ and $F_{2}$ are considered 1.05 and 1.1 , respectively. As a result, correction factor of 1.155 is applied to over-strength factor. Depending on the availability of reliable data, some other factors, such as nonstructural member contribution, can be involved in the correction factor.

The behavior factor calculated for LRFD (Load and Resistance Factored Design) method should be altered for ASD (Allowable Stress Design) method, using a modification factor ranging 1.4 to 1.5 , for $\mathrm{H}$-shape sections [21].

According to above-mentioned description, behavior factor can be obtained through Eq. (4), for LRFD design method.

$$
R=\frac{V_{e}}{V_{s}} \times F_{1} \times F_{2} \times \ldots=\frac{V_{e}}{V_{y}} \times \frac{V_{y}}{V_{s}} \times F_{1} \times F_{2} \times \ldots=R_{\mu} \times R_{S}
$$

Using values of maximum roof displacement and base shear for different intensity values (obtained from IDA analysis), idealized bilinear behavior parameters of the structure can be determined. The roof displacement values obtained from nonlinear dynamic analyses $\left(\Delta_{\max }\right)$ divided by the roof displacement corresponding to the yield point of idealized system $\Delta_{y}$ ) results in ductility factor $(\mu)$. Also, the over-strength factor $\left(R_{s 0}\right)$ can be determined by dividing the value of $V_{y}$ (maximum base shear obtained from nonlinear dynamic analysis) by $V_{s}$ (base shear corresponding to onset of significant nonlinearity). The actual over-strength can be obtained by multiplying $R_{s o}$ by correction factors $\left(F_{1}, F_{2} \ldots\right)$.

\section{Sample SMRF structures and analytical models}

Three 3-bay special moment-resisting frames involving 3, 6 and 10 stories, are selected as the sample structures. For all cases, the story height and bay width are equal to $3.2 \mathrm{~m}$ and $6 \mathrm{~m}$, respectively. Configuration and geometrical properties of the frames are presented in Fig. 2. Design frame sections are listed in Table 1. Loading and design of the buildings are in accordance with ASCE 2010 [15] and AISC 2010 Codes [22]. For all frames and stories, dead and live loads are taken as 500 and $250 \mathrm{~kg} / \mathrm{m}^{2}$ respectively. The loading dimensions, perpendicular to the frame planes are $6 \mathrm{~m}$.

Numerical modeling and nonlinear analyses are prepared and conducted using finite element software SeismoStruct v6.0 [23]. The software is commonly used for nonlinear modeling of structural systems subjected to different type of loading, especially seismic loads. It takes benefit of some advanced features such as "fiber based plastic frame elements with predefined nonlinearity length". Moreover, it supports incremental dynamic analysis.

The solution algorithm is fairly flexible since it allows the employment of Newton-Raphson (NR), modified Newton-Raphson (mNR) or NR-mNR hybrid solution procedures. It is clear that the computational savings in the formation, assembly and reduction of the stiffness matrix during the iterative process can be 


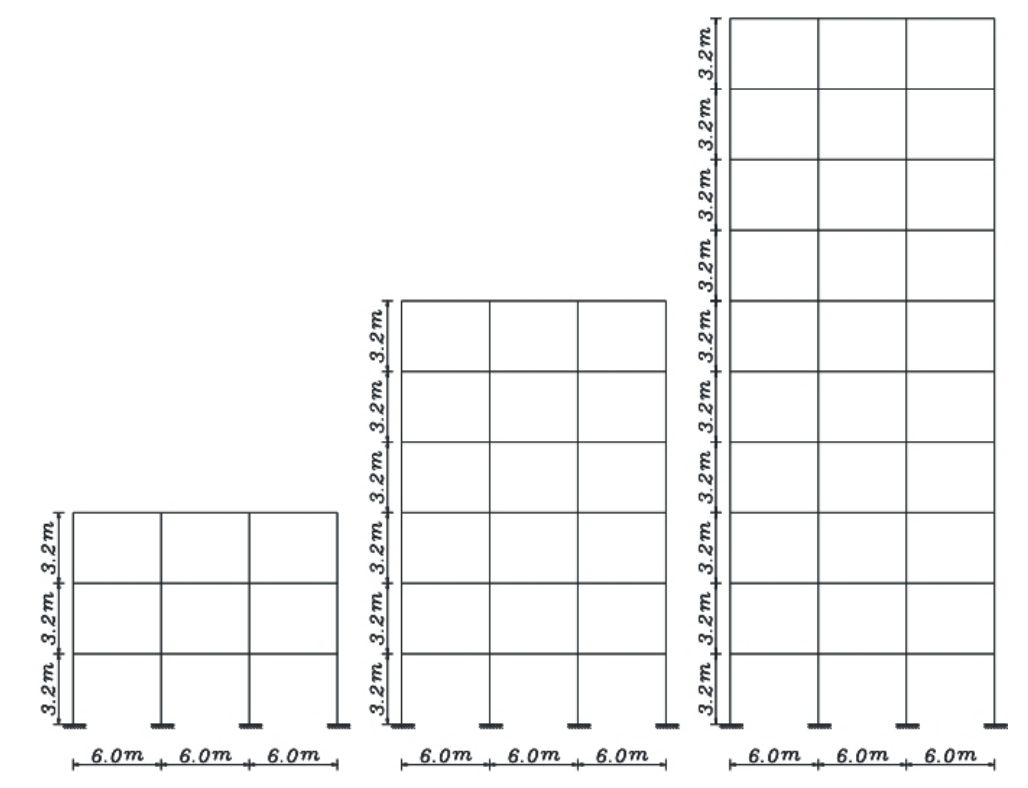

Fig. 2. Structure configurations.

significant when using the mNR instead of the NR procedures, so it is used in performing the analyses.

In addition, the software considers the local and global geometric nonlinearity and different cyclic behavior models are provided in definition of materials to model the nonlinear behavior of sections. By assigning an accurate cyclic behavior to materials, and then the selection of element integration method (for fiber-based frame elements), it would be possible to model the seismic behavior of elements. Verification examples for this software are presented in the software website [23].

In this paper, beam and column elements are modeled using force-based plastic hinge (FBPH) elements [24]. For this kind of elements, the nonlinearity is limited to a fraction of element length in two ends. This fraction is selected to equal to $15 \%$ for columns and beams.

All columns and beams fiber sections are divided into 200 fibers extending along the total length of members. The number of integration points for finite element model of frame elements is equal to four.

The rigid diaphragm assumption is made to model floors. In addition, penalty approach is employed for constraining the nodes located in the same diaphragms. The Rayleigh damping with $2 \%$ damping ratio for first mode and $5 \%$ for second mode of vibration is considered in nonlinear time-history analyses. The implicit integration used in time-history analyses is based on the Hilber-Hughes-Taylor algorithm.

The software takes geometrical nonlinearity effects (including $\mathrm{P}-\Delta$ ) into account, by default. The steel grade St-37 with yield strength of $240 \mathrm{Mpa}$ and modulus of elasticity of $210 \mathrm{Gpa}$, is used as section material of all members. Nonlinear material cyclic behavior is modeled by symmetric bilinear stressstrain curve with $3 \%$ of strain hardening ratio. However, there are some more elaborated modeling approaches to capture hysteretic behavior of steel frame members, the simpler method uti- lized in this research seems to be accurate enough for the goals of current work (comparative evaluation of $R$ factor for two different types of ground motions). Rigid diaphragm assumption is considered to model floors. The seismic mass for earthquake load calculations equals to 25 percent of total live load and full dead load of each story.

Tab. 1. Design sections of sample SMRF structures

\begin{tabular}{|c|c|c|}
\hline Story & Column & Girder \\
\hline \multicolumn{3}{|c|}{ (1) 3-story MRF (period for the $1^{\text {st }}$ vibration mode $=0.86 \mathrm{~s}$ ) } \\
\hline $3 F-1 F$ & Box280 $\times 280 \times 10$ & $\mathrm{H} 300 \times 200 \times 10 \times 14^{a}$ \\
\hline \multicolumn{3}{|c|}{ (2) 6-story MRF (period for the $1^{\text {st }}$ vibration mode $=1.22 \mathrm{~s}$ ) } \\
\hline $6 \mathrm{~F}-4 \mathrm{~F}$ & Box280 $\times 280 \times 10$ & $\mathrm{H} 260 \times 180 \times 10 \times 14$ \\
\hline $3 \mathrm{~F}-1 \mathrm{~F}$ & Box280 ×280 ×15 & $\mathrm{H} 300 \times 200 \times 10 \times 14$ \\
\hline \multicolumn{3}{|c|}{ (3) 10 -story MRF (period for the $1^{s t}$ vibration mode $=1.69 \mathrm{~s}$ ) } \\
\hline $10 \mathrm{~F}-9 \mathrm{~F}$ & Box260 ×260 ×16 & $\mathrm{H} 300 \times 160 \times 10 \times 20$ \\
\hline $8 \mathrm{~F}-7 \mathrm{~F}$ & Box320 ×320 ×16 & $\mathrm{H} 340 \times 200 \times 12 \times 20$ \\
\hline $6 \mathrm{~F}$ & Box340 $\times 340 \times 20$ & $\mathrm{H} 340 \times 200 \times 12 \times 20$ \\
\hline $5 \mathrm{~F}-4 \mathrm{~F}$ & Box340 ×340 ×20 & $\mathrm{H} 380 \times 200 \times 12 \times 20$ \\
\hline $3 F-1 F$ & Box380 $\times 380 \times 20$ & $\mathrm{H} 380 \times 200 \times 12 \times 20$ \\
\hline
\end{tabular}

\section{Results and discussions}

Tab. 2. Drift angle limits for LS and CP limit states according to FEMA 356

\begin{tabular}{lc}
\hline Limit states/ drift limits & Steel moment frames \\
\hline Immediate Occupancy & $0.7 \%$ \\
\hline Life Safety & $2.5 \%$ \\
\hline Collapse Prevention & $5 \%$ \\
\hline
\end{tabular}

According to the procedure described in section (3), seismic performance parameters (including ductility, $\mu$, over-strength, $R_{s}$, force reduction due to ductility, $R_{\mu}$ and $R$ factor) are estimated for three example SMRF structures using IDA analysis, considering near and far fault ground motion records. Simply, the product of $\left(R_{\mu} \times R_{s}\right)$ yields the $R$ factor. 
Tab. 3. List of ground motion records used in incremental dynamic analyses

\begin{tabular}{cccc}
\hline Earthquake site/component/date & Magnitude & $\mathrm{R}(\mathrm{km})$ & $\mathrm{PGA}(\mathrm{g})$ \\
\hline (1) ordinary ground motions & & & \\
\hline Chi-Chi CHY101-W, Taiwan, September 20, 1999 & 7.6 & 11.14 & 0.353 \\
\hline Imperial Valley, H-E01240, October 15, 1979 & 6.5 & 10.4 & 0.315 \\
\hline Loma Prieta, G02090, October, 1989 & 6.9 & 12.7 & 0.322 \\
\hline Loma Prieta, G03090, October 18, 1989 & 6.9 & 14.4 & 0.367 \\
\hline Northridge, CNP 196, January 17, 1994 & 6.7 & 15.8 & 0.42 \\
\hline Northridge, LOS000, January 17, 1994 & 6.7 & 13 & 0.41 \\
\hline Tabas, BOS-T1, September 16, 1978 & 7.4 & 26.1 & 0.089 \\
\hline Kobe, HIK000, January 16,1995 & 6.9 & 95.72 & 0.143 \\
\hline N. Palm Springs, TFS000, July 8, 1986 & 6.06 & 64.8 & 0.121 \\
\hline Manjil, 188040, June 20,1990 & 7.37 & 64.67 & 0.097 \\
\hline (2) Pulse like ground motions & & & 0.419 \\
\hline Chi-Chi, TCU052-N, Taiwan, September 20, 1999 & 7.6 & 0.24 & 0.566 \\
\hline Chi-Chi, TCU068-W, Taiwan, September 20, 1999 & 7.6 & 1.09 & 0.496 \\
\hline Erzincan, ERZ-EW, March 13, 1992 & 6.9 & 2 & 0.838 \\
\hline Northridge, RRS228, January 17, 1994 & 6.7 & 7.1 & 0.843 \\
\hline Northridge, SYL360, January 17, 1994 & 6.7 & 6.4 & 0.25 \\
\hline Landers, LUCMV1-280, 1992 & 7.3 & 23.6 & 0.322 \\
\hline Loma Prieta, 0090, October 18, 1989 & 6.9 & 11.1 & 0.16 \\
\hline Imperial Valley, H-BRA225, October 15, 1979 & 6.5 & 10.4 & 0.693 \\
\hline Kobe, KJMA000, January 16,1995 & 6.9 & 0.3 \\
\hline Cape Mendocino, Petrolia000, 1992 & 7 & 8.2 & \\
\hline
\end{tabular}

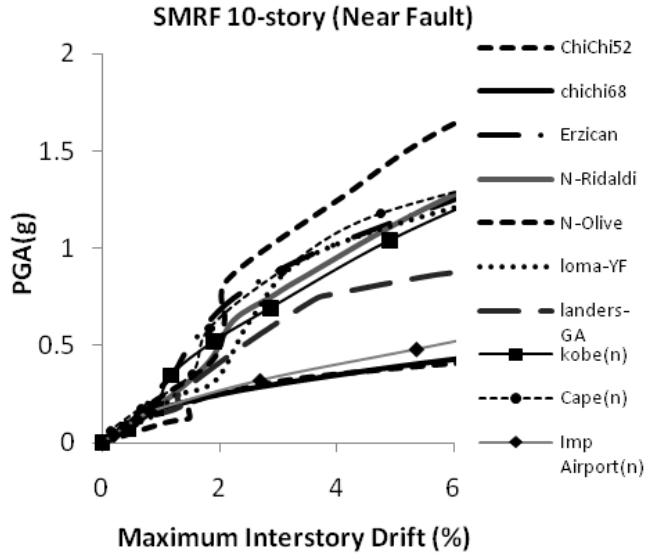

(a)

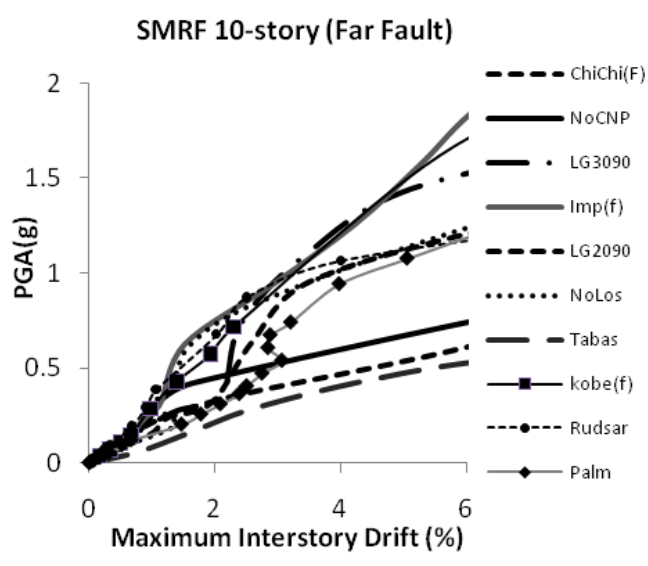

(b)

Fig. 3. IDA curves for 10-story SMRF structure, in term of PGA and inter-story drift ratio under: (a) near-fault ground motions (b) ordinary ground motions

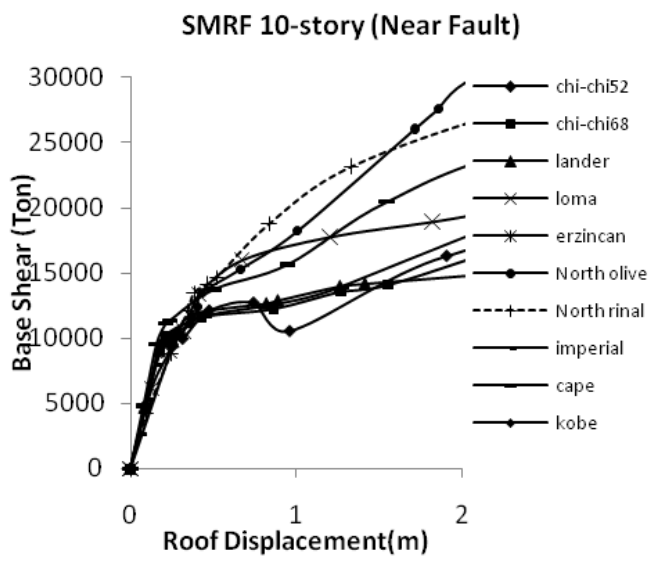

(a)

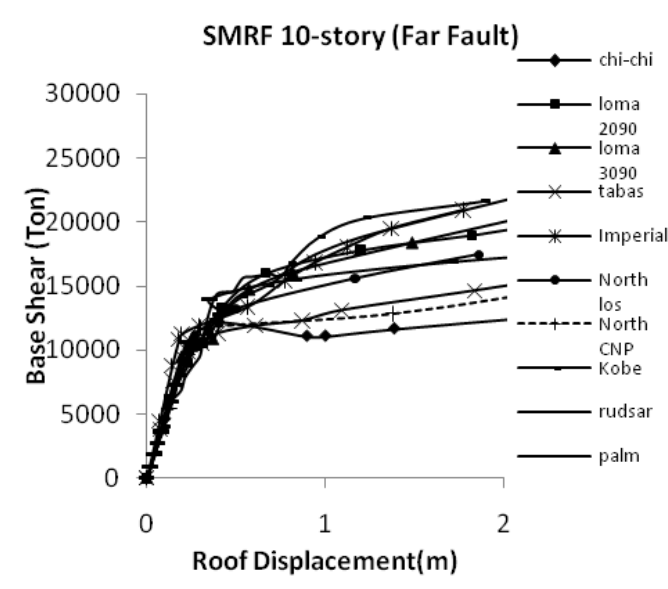

(b)

Fig. 4. IDA curves for 10-story SMRF structure, in terms of base shear-roof displacement under: (a) near-fault ground motions (b) ordinary 
Tab. 4. Average values of nonlinear and linear base shear obtained from IDA analyses.

\begin{tabular}{cccccc}
\hline \multirow{2}{*}{$\begin{array}{c}\text { No. } \\
\text { story }\end{array}$} & Limit & \multicolumn{2}{c}{ Ordinary Ground motions } & \multicolumn{2}{c}{ Near-Fault Ground motions } \\
\cline { 3 - 6 } & State & $V_{y(\text { avg })}$ & $V_{e(\text { avg })}$ & $V_{y(\text { avg })}$ & $V_{e(\text { avg })}$ \\
\hline 3 & LS & 699.2 & 2810.7 & 674.6 & 2076.5 \\
\hline 6 & LS & 1041.1 & 4220.7 & 1024.6 & 3258.9 \\
\hline 10 & LS & 1333.4 & 5614.6 & 1371.3 & 4352.5 \\
\hline 3 & CP & 789.4 & 4467.2 & 776.7 & 3873.3 \\
\hline 6 & CP & 1279.2 & 8098.5 & 1246.1 & 6984.2 \\
\hline 10 & CP & 1780.5 & 12256.6 & 1603.5 & 9671.4 \\
\hline
\end{tabular}

Tab. 5. Behavior factors of SMRFs for ordinary ground motions

\begin{tabular}{ccccccc}
\hline No. story & Limit State & $V_{s}$ (Ton) & $R_{s}$ & $R_{\mu}$ & $\mathrm{R}$ & $\mu$ \\
\hline 3 & LS & 501.4 & 1.59 & 2.9 & 4.61 & 1.72 \\
\hline 6 & LS & 720.2 & 1.62 & 2.96 & 4.8 & 1.83 \\
\hline 10 & LS & 1021.5 & 1.58 & 3.14 & 4.96 & 2.32 \\
\hline 3 & CP & 501.4 & 1.74 & 3.65 & 6.35 & 2.65 \\
\hline 6 & CP & 720.2 & 1.96 & 3.84 & 7.53 & 2.86 \\
\hline 10 & CP & 1021.5 & 1.9 & 4.25 & 8.07 & 3.53 \\
\hline
\end{tabular}

Incremental dynamic analysis is applied to determine the base shear, story displacements and other required response quantities. In this paper, performance points are defined following the FEMA $356[8]$ implications, as shown in Table 2 In addition, a try-and-error procedure is followed to get prescribed performance points, where nonlinear dynamic analyses are implemented with different scale factors until the maximum interstory drift ratio reaches predetermined values or structural instability occurs. Structural instability is considered as the state in which a slight increase in ground motion intensity leads to significant increase in displacement response of the structure [25]. In this study, behavior factor is calculated for LS and CP limit states.

To find the point at which the first structural nonlinearity begins; pushover analysis approach is applied. In other words, it is assumed that the pushover method can appropriately predict the moment in which nonlinearity onsets. The lateral loading pattern corresponding to the $1^{\text {st }}$ mode of vibration is applied in pushover analyses, since the modal mass participation ratio of higher modes fall in a range that allows for neglecting the effect of higher modes.

Two sets of far fault and near fault ground motion records are used for performing IDA analyses. Beside the estimation of absolute value of $R$ factor, comparisons are made between the $R$ values related to far and near-fault ground motion records. Detail of ground motion records can be found in Table 3 .

The results of nonlinear IDA analysis for 10 story SMRF structure are presented in Fig. 3, in terms of PGA and maximum inter-story drift ratio. Also, the results are presented in Fig. 4 . in terms of maximum base shear and roof displacement. As can be seen, IDA curves are plotted for two sets of far and near fault ground motions.

Average values of maximum base shear resulted from linear and nonlinear IDA analyses $\left(V_{e}\right.$ and $\left.V_{y}\right)$ are listed in Table 4 Finally, the average values of parameters used for calculation of $R$ factors (including $V_{s}$, over-strength factor, $R_{s}$, ductility, $\mu$ ) and the average values of $R_{\mu}$ and $R$ factor are listed in Tables 5 and 6 for ordinary and near fault ground motions, respectively. All the parameters presented in Tables 5 and 6 are given for LS and CP limit states. So, the values can be utilized for performance-based design of SMRF structures.

As it is expected, the value of base shear for collapse prevention limit state is considerably larger than that of life safety. Comparison of elastic base shear for near and far fault records reveals that for a specific limit state, sample structures have larger elastic base shear for far field records. It is because the shock features of near fault records, resulting in the reduction of structural capacity to resist levels of lateral forces. A translation for this result is that the structural capacity to dissipate input seismic energy is extremely affected by the impulsive feature of ground motion records. This effect combines with the larger spectral values of near fault records to make them very destructive to structural systems.

The comparison of performance based parameters shown in Tables 5 and 6 reveals that the $R$ factor is highly dependent to performance level under consideration. The average value of $R$ factor for CP limit state is averagely 52\% larger than LS limit state, due to higher displacement demand in CP limit state. However, the result can be changed if the definition of LS and CP limit states are changed. In addition, it can be seen that the $R$ factor is much larger for ordinary ground motions than near fault ground motions. In average, $R$ factor value is $23 \%$ larger for ordinary earthquake records compared to near fault records. Most of the difference between the values of $R$ factor for near and far fault records arises from difference in ductility capacity. Near fault records with impulsive characteristics lead to con- 
Tab. 6. Behavior factor of SMRFs for near fault ground motions

\begin{tabular}{ccccccc}
\hline No. story & Limit State & $V_{s}($ Ton $)$ & $R_{s}$ & $R_{\mu}$ & $\mathrm{R}$ & $\mu$ \\
\hline 3 & LS & 501.4 & 1.57 & 2.37 & 3.72 & 1.64 \\
\hline 6 & LS & 720.2 & 1.7 & 2.11 & 3.59 & 1.58 \\
\hline 10 & LS & 1021.5 & 1.46 & 2.43 & 3.55 & 2.09 \\
\hline 3 & CP & 501.4 & 1.72 & 3.41 & 5.87 & 2.44 \\
\hline 6 & CP & 720.2 & 1.95 & 3.35 & 6.53 & 2.21 \\
\hline 10 & CP & 1021.5 & 1.7 & 4.02 & 6.83 & 3.24 \\
\hline
\end{tabular}

centration of ductility demands in some specific floor levels that mainly depends upon the pulse period and structural properties. When subjected to shock-like near fault records, structural system would have not enough time to distribute the input energy in all components of lateral force resisting system and consequently the damage will accumulate in a limited number of elements in specific floor levels. For example, the coefficient of variation $(\mathrm{COV})$ for values of maximum inter-story drift ratio of floor levels for 10-story frame, are averagely equal to 0.63 and 0.73 for far and near fault ground motion record sets, respectively. This observation indicates that the drift distribution along the frame height is more uniform for far field records compared to near fault ones. Consequently, the damage induced by near fault records is accumulated in limited parts of the structure This phenomenon reduces the ductility capacity of structures, which leads to decrease in value of $R$ factor. For the structures under study, the effect of pulse-like records on higher structures is more pronounced, as the ratios of $\mathrm{R}$ values for far fault to near fault records $\left(R_{\text {far }} / R_{\text {near }}\right)$, for 3, 6 and 10 story frames, equal to $1.2,1.34$ and 1.40 , in Life Safety limit state. These values equal to $1.08,1.15$ and 1.18 for Collapse Prevention limit state. This is due to the fact that the distribution of displacements along the height of the structures tends to be uniform in the case of lowrise structures. Furthermore, the period of low-rise buildings are usually smaller than period of ground motion pulse which leads to reduction of near fault effects. Therefore, near fault records have less influence on lower height buildings compared with higher ones.

According to above-mentioned statements, it seems that the value of $R$ factor should be taken smaller, when structure is expected to experience pulse-like ground motions, especially for mid-rise to high-rise structures.

\section{Conclusions}

In this paper, behavior factor and seismic performance parameters (over-strength and ductility factors) of steel moment resisting frames are estimated and compared for near and far fault ground motions. To this end, an analytical method using the result of incremental dynamic analysis is employed. Two levels of performance (LS and CP) are considered as target limit states. The study demonstrates that the seismic capacity of the MRF structures decreases when subjected to near fault records, which this phenomenon can be represented by reducing the behavior factor in a logical manner. Furthermore, with increase in height, the influence of near fault earthquakes is more pronounced.

The numerical results of study are summarized as follows:

1 For LS limit state, the average over-strength of the SMRF structures is evaluated as 1.6 and 1.58 , for ordinary and nearfault ground motions. These values are 1.87 and 1.79 for $\mathrm{CP}$ limit state, respectively.

2 For LS limit state, the average ductility $(\mu)$ of the SMRF structures is evaluated as 1.96 and 1.77 for ordinary and near-fault ground motions. These values are 3.01 and 2.63 for CP limit state.

3 The average value of $R$ factors for SMRF structures is obtained as 4.79 and 7.31 for LS and CP limit states, respectively, considering ordinary ground motions. These values change to 3.62 and 6.41 when near fault records are considered.

$4 R$ factor values evaluated for CP limit state are about $52 \%$ larger than LS limit state, averagely. In addition, the average $R$ factor calculated for ordinary ground motions is normally $23 \%$ larger than near fault records.

\section{References}

1 Asgarian B, Shokrgozar HR, BRBF response modification factor, Journal of Constructional Steel Research, 65(2), (2009), 290-298, DOI 10.1016/j.jcsr.2008.08.002

2 Asgarian B, Sadrinezhad A, Alanjari P, Seismic performance evaluation of steel moment resisting frames through incremental dynamic analysis, Journal of Constructional Steel Research, 66, (2010), 178-190, DOI 10.1016/j.jcsr.2009.09.001

3 Luco N, Cornell CA, Effects of random connection fractures on demands and reliability for a 3-story pre-Northridge SMRF structure, Proceedings of the 6th US national conference on earthquake engineering, In: Seismic Design and Mitigation for the Third Millennium; Seattle, Washington, 1998, pp. 1-12.

4 Yun SY, Hamburger RO, Cornell CA, Foutch DA, Seismic performance evaluation for steel moment frames, ASCE Journal of Structural Engineering, 128, (2002), 534-545, DOI 10.1061/(ASCE)0733-9445(2002)128:4(534)

5 Özhendekci D, Özhendekci N, Seismic performance of steel special moment resisting frames with different span arrangements, Journal of Constructional Steel Research, 72, (2012), 51-60, DOI 10.1016/j.jcsr.2011.10.002

6 Xue Q, Wu CH, Chen $\mathbf{C H}$, Chen $\mathbf{K}$, The draft code for performance-based seismic design of buildings in Taiwan, Engineering Structures, 30, (2008), 1535-1547, DOI 10.1016/j.engstruct.2007.10.002 
7 Aksoylar ND, Elnashai AS, Mahmoud H, The The design and seismic performance of low-rise long-span frames with semi-rigid connections, Journal of Constructional Steel Research, 67, (2010), 114-126, DOI 10.1016/j.jcsr.2010.07.001

8 American Society of Civil Engineers, Prestandard and Commentary for the Seismic Rehabilitation of Buildings, FEMA356, ASCE, 2000.

9 Baker J, Cornell CA, Vector-valued intensity measures for pulse-like nearfault ground motions, Engineering structures, 30, (2008), 1048-1057, DOI 10.1016/j.engstruct.2007.07.009

10 Kalkan E, Kunnath S, Effects of fling step and forward directivity on seismic response of buildings, Earthquake Spectra, 22, (2006), 367-390, DOI 10.1193/1.2192560

11 Gerami M, Abdollahzadeh D, Local and global effects of forward directivity, Journal of the Croatian Association of Civil Engineers, 65, (2013), 1015-1029.

12 Gillie JM, Rodriguez-Marek A, McDaniel C, Strength reduction factors for near-fault forward-directivity ground motions, Engineering Structures, 32, (2010), 273-285, DOI 10.1016/j.engstruct.2009.09.014

13 Baker J, Quantitative classification of near-fault ground motions using wavelet analysis, Bulletin of the Seismological Society of America, 97, (2007), 1486-1501, DOI 10.1785/0120060255

14 Applied Technology Council, A critical review of current approaches to earthquake-resistant design, ATC-34, Applied Technology Council, 1995.

15 American Society of Civil Engineers, Minimum design loads for buildings and other structures, ASCE Standard 07-10, ASCE, 2010.

16 Izadiniaa M, Rahgozar M, Mohammadrezae O, Response modification factor for steel moment-resisting frames by different pushover analysis methods, Journal of Constructional Steel Research, 79, (2012), 83-90, DOI 10.1016/j.jcsr.2012.07.010

17 Kang Ch, Choi B, New Approach to Evaluate the Response Modification Factors for Steel Moment Resisting Frames, International Journal of Steel Structures, 11, (2011), 275-286, DOI 10.1007/s13296-011-3003-1

18 Karavasilis T, Bazeos N, Bazeos D, Behavior Factor for PerformanceBased Seismic Design of Plane Steel Moment Resisting Frames, Journal of Earthquake Engineering, 11, (2007), 531-559, DOI 10.1080/13632460601031284

19 Fanaie N, Ezzatshoar S, Studying the seismic behavior of gate braced frames by incremental dynamic analysis (IDA), Journal of Constructional Steel Research, 99, (2014), 111-120, DOI 10.1016/j.jcsr.2014.04.008

20 Schmidt BJ, Bartlett FM, Review of resistance factor for steel: Resistance distributions and resistance factor calibration, Canadian Journal of Civil Engineering, 29, (2002), 109-118, DOI 10.1139/101-082

21 Uang CM, $R$ (or $R w$ ) and Cd factor for building seismic provision, Journal of Structure Engineering, 117, (1991), 19-28, DOI 10.1061/(ASCE)07339445(1991)117:1(19))

22 Institute of steel construction, Specification for Structural Steel Buildings American, AISC, 2010.

23 Seismo Struct,: A computer program for static and dynamic analysis for framed structures. Version 6.0, 2012, www. seismosoft.com Seismo Software.

24 Scott MH, Fenvese GL, Plastic hinge integration method for forcebased beam-column elements, ASCE Journal of Structural Engineering, 132, (2006), 244-252, DOI 10.1061/(ASCE)0733-9445(2006)132:2(244)

25 Vamvatsikos D, Cornell CA, Incremental Dynamic Analysis, Earthquake Engineering and Structural Dynamics, 31, (2002), 491-514, DOI 10.1002/eqe. 141 